to find his way readily to any part of it. In the one before us this want is met by an admirable index, and an equally complete table of contents, and by the liberal use of clarendon type in the body of the book. The printing is clear and generally correct, but we notice the following errata :-

P.x. line 8 from top, for " $1885-1888$ " read "I $883-1888$."

P. IIO, in the heading of Chapter VI., for " $64 \mathrm{I}-1543$ " read "64I-1453."

P. I68, line 4 from bottom, for "Act iv. sc. 3 " read "Act iv. sc. 2."

P. 358 , line 8 from bottom, for "I728" read " 1738 ."

All the salient points of mathematical history are given, and many of the results of recent antiquarian research; but it must not be imagined that the book is at all dry. On the contrary, the biographical sketches frequently contain amusing anecdotes, many of the theorems mentioned are very clearly explained, so as to bring them within the grasp of those who are only acquainted with elementary mathematics, and there is a very interesting account (in a footnote) of the early history of the Universities of Paris, Oxford, and Cambridge. For those who wish to study mathematical history in detail there is a long list of authorities at the beginning, and many references to other works are made in different parts of the book. We would suggest that in future editions reference should be made to "Les Fondateurs de l'Astronomie Moderne Copernic-Tycho Brahé, Képler, Galilee, Newton," by Joseph Bertrand (8vo, Paris, n.d.), and to the article "Viga Ganita" in the "Penny Cyclopædia" (which contains the opinions of Colebrooke, the translator of the "Lilavati," \&c., on many points connected with Hindu mathematics).

Finally, we would suggest that the following motto should be printed on the title-page of the second edition :-

"Habetis originis ac progressionis mathematica historiam brevem. Ex qua matheseos antiquitas, præstantia, ac dignitas apparet."

The quotation is taken from the concluding paragraph of the "Historica Narratio" prefixed to Andrew Tacquet's "Euclid" (2nd ed., by Whiston, 1710). It describes perfectly the contents of the present treatise.

Mr. Ball promises us a supplementary volume containing a list of mathematicians and their works, which is to be as complete as possible. It will be a most import ant contribution to mathematical bibliography, and we sincerely hope that the reception that this volume meets with will encourage him to write the supplement.

\section{THE BUILDING OF THE BRITISH ISLES.}

The Building of the British Isles: a Study in Geographical Evolution. By A. J. Jukes-Browne, B.A., F.G.S. (London: George Bell and Sons, 1888.)

$\mathrm{T} T$ is now thirty-three years since Godwin-Austen, in 1 a paper which glows with the instinctive perception that is one of the marks of genius, suggested to geologists an application of their science which lifts it out of the region of technicalities, gives it a human interest, and attracts all those who care to follow the long chain of events of which the present state of things is the outcome. It was an attempt to go back to Mesozoic and Palæozoic days, and mark out the main outlines of the physical geography of Great Britain and the adjoining parts of Europe during those epochs. To enable its conclusions to be more easily grasped, the paper was accompanied by a map, almost bewildering in its complexity and somewhat hazy in its outlines, but full of the masterly generalization that marshals into one compact body a crowd of isolated facts, and of the intuition that foresees the complete meaning of imperfectly ascertained data.

Many a geologist has since been tempted to try his hand at similar tasks, but few have mustered courage, when it came to the point, to embody their conclusions in a map. And no wonder : everyone who has speculated in this direction knows how easy it is to clothe his conceptions in words, and soon finds out how hard verbal descriptions of physical geography are to follow. So he becomes keenly alive to the fact that, if he wishes to be listened to, he must make the road easy by presenting his restorations to the eye in the pictoral form of a map. But if he be haunted by any sense of accuracy, and any horror of vagueness and hasty reasoning, he finds himself beset on all sides, when he begins to plot out his map, with uncertainties and hesitations that give him pause. It may be easy to say that land lay on this side and sea on that, but when a coast-line is actually to be laid down, though it may be possible to fix the limits between which it must lie, these limits are often so wide apart that the feeling of uncertainty as to the actual position of the boundary becomes unbearable, and the prospect of making a map that shall be even approximately accurate grows hopeless. Worse still is it-and this not unfrequently happens-when there are not even bounding limits, and the coast-lines can be no better than such guess-work as rashness delights in and the logical temperament abhors.

But even those who realize most clearly the difficulties of the task of making maps which show the distribution of land and sea during past geological epochs, welcome with keen delight attempts, such as those in the book before us, which are made in the right spirit ; and it would ill become me to carp at the author's restorations, even were they less satisfactory than is the case, for I believe that, in noticing a former work of his, I ventured to take him to task for not having appended maps to his verbal descriptions of the old physical geography of our islands.

Mr. Jukes-Browne has explained, in the introduction, the principles which have been his guide ; and the words with which he concludes his opening remarks show how fully he is aware of the difficulties that attend the task he has undertaken, and how much uncertainty hangs over many of his results. Even where we cannot agree with him, we feel sure that he has never been hasty and has spared no pains to arrive at the most probable conclusions.

With commendable caution no attempts are made to depict on a map the physical geography of Archæan and Cambrian times; but preference is given to Prof. Hull's conjecture that the great mass of Cambrian land "lay to the north-west of Europe, and occupied a large part of what is now the North Atlantic Ocean." The words "large part" are vague, but a partiality for filling up the 
Atlantic on slight provocation is, I fear, rife among us, and ought not to be encouraged.

The Ordovician and Silturian maps are probably as near approximations as the present state of our knowledge allows-maybe as we shall ever attain to. In the Lower Old Red Sandstone map, the Old Red of South Wales is represented as having been formed in a bay of the Devonian sea. This view does get over some difficulties. If we suppose it formed in a fresh-water lake, we must admit that the barrier separating the lake from the Devonian sea was narrow, and, as our author remarks, there is no independent evidence for the existence of such a barrier. The absence, as far as we know, of any marine fossils tells the other way, but the district is yet geologically almost a terra incognita, and we must wait before the question can be settled. In the same way it must be confessed that it is hard to see on what grounds the Glengariff Grits are classed as marine; but here again the "retort courteous" might be, "What reason have you for thinking them fresh-water deposits?" It is too large a question to go into here.

The Carboniferous map I turned to with the greatest curiosity, for it so happens that years ago I was rash enough to try my hand at a similar production. The thing has thrust itself upon me many times since, and each time I have seen something in it that dissatisfied me, and it has been touched up and tinkered till now I hardly recognize my own child; and till I know my own mind, it would be hardly fair, even supposing it possible, to attack another man for differing from me. Really, the two maps have more in common than appears at first sight ; and on some points of fundamental importancethe land-locked character of the Carboniferous sea for instance-Mr. Jukes-Browne and I are in complete accord. I should not have ventured on this bit of personal reminiscence, if it had not been that it seemed to me that it may possibly be typical. Put a number of equally qualified men to construct one of these geographical restorations, and the result will probably be this: there will be some few points on which all must agree; but the data for settling details will be so vague, that no two maps will be alike in their minor points. Even if this be so, it by no means proves the work to be unprofitable; but it is as well to bear this in mind when comparing two independent restorations.

Space will not allow of detailed criticism of the series of maps with which the book is lavishly illustrated; but all readers will gratefully thank the author for the pains he has taken to render such effectual help to them in following his reasoning. Every chapter bears the mark of patient and conscientious work; and though in a book of this size no more than an abridged and concise statement of many of its facts can find a place, its suggestiveness will insensibly lead the real student to the original papers of which it is an epitome, and open for him a wide field of reading.

The chapter on the Pleistocene epoch is one on which the author has evidently spent much pains, but it seems to me the least satisfactory in the book. With much that he says I heartily agree. I cannot help feeling that some of our most eminent glacialists have ridden their theories rather hard. That the Scotch Till is a moraine profonde seems to me the only hypothesis yet put forward which gives anything like a satisfactory explanation of the origin of that deposit; but I am not prepared to admit a like origin for all the so-called Boulder-clays: most of those who have studied on the ground in detail the Boulder-clays of the plains of Lancashire and Cheshire have come to the conclusion that they are submarine, and that their boulders have been supplied by floating ice. Some of the objections which Mr. Jukes-Browne urges against the ground-moraine theory, however, do not seem to me serious. He cannot understand how it is that an ice-sheet could groove and polish the rocks and form a ground-moraine at the same time. There are many ways out of the difficulty. Ice-scratching is most conspicuous on high ground and steep slopes, where there is little or no Till. It is true that it is far from uncommon on lower and flatter ground, where it is covered and indeed preserved by a coating of Till. Here it may be the first work of the icesheet before much débris had been dragged down from the hill country : but we must also bear in mind the probable character of a ground-moraine: packed closely by the weight of the ice above and frozen hard, it would be very different from the imperfectly consolidated mass we see now: rather it would act as a solid whole, and, as it was dragged along, would be quite capable of effecting a large amount of abrasion. The alternative which is suggested involves the floating of the ice-sheets bodily over wide extents of sea ; but, as far as we know, ice-sheets do not float as a whole when they push their way out to sea, they break up into icebergs. We may picture to ourselves the probable action of an ice-sheet somewhat after this fashion. While descending slopes even moderately steep, it would push before it and drag beneath it any loose débris that it found ready made to its hand or that it had itself torn off the surface. But here its motive power would be sufficient to carry with it all the loose matter; consequently here no Till would be formed, unless the sheet happened to encounter a gorge in its path. In such a case the stones and dirt would be driven into the hollow till they filled it up, and the ice would then ride over it. When the icesheet reached flatter ground, its dragging power would be seriously diminished: it would probably at first heap up the débris into a mound or ridge in front of it: this mound after a time it would override, and flatten and spread out its materials; by a continuance of the process a sheet of Till would be spread over the lowlands. Of course here too any valley that lay athwart the path of the ice would be filled up. Thus would be produced exactly the distribution of the Till which occurs: in the hill-country little or none except as filling in valleys; over the plains a broad sheet, and great thicknesses in the valleys of the low country. So that when our author states that Prof. James Geikie"s views might be accepted "if the Boulder-clay was found to fill in lake-like hollows," he is describing very nearly an essential feature in the actual manner of its occurrence.

Having now discharged the functions of the critic, and pointed out what appear to me some weak points, I will only add that if I seem to have been scant of praise, it is because there was no need. The book recommends itself.

A. H. GREEN. 